\title{
Recent Possibilities for the Diagnosis and Pharmacological Control of Pregnancy Loss in Dairy Cow
}

\author{
Ottó Szenci \\ MTA-SZIE Large Animal Clinical Research Group, Üllö-Dóra Major, H-2225 Hungary
}

Received: March 30, 2015 / Accepted: April 12, 2015 / Published: April 30, 2015.

\begin{abstract}
One of the most recent techniques for the diagnosis of EP (early pregnancy) in cattle on the farm is B-mode ultrasonography. Under field conditions, acceptable results may be achieved with ultrasonography from days 25 to 30 post-AI. The reliability of the test greatly depends on the frequency of the transducer used, the skill of the examiner, the criterion used for a positive PD (pregnancy diagnosis) and the position of the uterus in the pelvic inlet. Pregnancy protein assays (PAG, PSPB) may provide an alternative method to ultrasonography for determining EP or LEM/EFM (late embryonic/early foetal mortality) in the cow. Although early pregnancy factor is the earliest specific indicator for fertilization, its detection is entirely dependend on the use of the RIT (rosette inhibition test), therefore its use in the field needs further inventions. Preventive pharmaceutical treatments with hCG (human chorionic gonadotropin), GnRH (gonadotropin realising hormone), PRID (progesterone-releasing intravaginal device) or CIDR (controlled internal drug release) inserts at different time periods at or post-AI may have some benefit in decreasing PL (pregnancy loss), however further examinations are warranted to determine how and when these treatments may influence PL in the field.
\end{abstract}

Key words: Dairy cow, embryonic mortality, foetal mortality, ultrasonography, pregnancy proteins, GnRH, hCG, progestagens.

\section{Introduction}

The extent of PL in dairy cows can be estimated from the difference between FR (fertilisation rate) and subsequent CR (calving rate). It is generally accepted that FR in healthy dairy cattle is of the order of 85 to $90 \%$ [1] and the CR is presently around 33 to $41 \%$. The CR has decreased from $66 \%$ since 1951 , to about $50 \%$ until 1975, and further more until recently to about 33.1\% in Spain [2], 33.4\% in Israel [3], 37\% in Canada [4] or $41 \%$ in Japan [5]. Therefore $44 \%$ to $58 \%$ of pregnancies are lost during gestation. Most of the losses may occur between days 8 and 16 post-AI (early embryonic mortality: EEM) [1]. Further 5\% to $10 \%$ losses may occur between days 16 and 42 (late embryonic mortality: LEM) and between days 42 to

Corresponding author: Ottó Szenci, DVM, Ph.D., D.Sc., professor, research field: bovine obstetrics and reproduction. E-mail: szenci.otto@aotk.szie.hu.
90 (early foetal mortality: EFM) post-AI, respectively while late foetal mortality between day 90 to term is rare [6]. The PL represents a considerable biological and economical waste.

The aim of the present review is to discuss the possible methods for diagnosing early pregnancy and PLs as well as the possibilities for preventive pharmaceutical treatments.

\section{Early Pregnancy Diagnosis (PD)}

\subsection{Real-Time B-mode Ultrasonography}

During UE (ultrasonographic examination), a cow is considered to be pregnant when an irregularly shaped, non-echogenic black spot (or spots) are recognised within the uterine lumen, representing the allantoic fluid. The demonstration of an embryo or a foetus provides additional confirmation of pregnancy. Where no such signs are found the possibility of 
pregnancy is ruled out, giving a non-pregnant diagnosis. The confirmation of ultrasonographic diagnoses is usually based on palpation per rectum of the uterus at two to three months post-AI, or upon spontaneous return to oestrus after AI. A cow is also considered pregnant if an embryo proper with a beating heart is recognised at a final UE on days 50 to 60 post-AI. Cows diagnosed as non-pregnant by palpation per rectum or by ultrasonography between days 50 to 90 are usually designated as non-pregnant [7-9].

Transrectal UE, using a $5.0 \mathrm{MHz}$ linear-array or sector transducer, is a moderately accurate method for selecting pregnant and non-pregnant cattle from as early as days 25 to 26 . Field studies reported that $2 \%$ to $5 \%$ of the calving animals were incorrectly diagnosed as non-pregnant, and $8.7 \%$ to $36 \%$ of the non-calving cows were incorrectly diagnosed as pregnant [10-12]. However, according to Badtram et al. [13], the sensitivity and specificity of the ultrasound test between days 23 and 31 post-AI were only $68.8 \%$ and $71.7 \%$, respectively. In a recent study, maximum sensitivity and negative predictive value were reached at day 26 in heifers and day 29 in cows [14].

Transrectal UE, using a $7.5 \mathrm{MHz}$ linear-array transducer, provides a method with an accuracy of more than $90 \%$ to select pregnant (sensitivity 90.4\%) and non-pregnant cattle (specificity 96.0\%) from day 29 or 30 onwards [15]. When the recognition of an embryo proper with a beating heart was used as the criterion for a positive ultrasound PD, significantly $(P$ $<0.001)$ more false negative and less false positive ultrasound diagnoses were made, in comparison with recognition of allantoic fluid [15].

Under field conditions, acceptable results may be achieved with ultrasonography (using 5 or $7.5 \mathrm{MHz}$ transducers) from days 25 to 30 after AI [10-12, 15, 16]. The reliability of the test greatly depends on the frequency of the transducer used, the skill of the operator [13], the criterion used for a positive pregnancy diagnosis [15] and the position of the uterus in the pelvic inlet [17]. More incorrect non-pregnancy diagnoses were made in cows between days 24 to 38 in which the uterus was located far cranial to the pelvic inlet, in comparison with cows in which the uterus was located within or close to the pelvic inlet [17].

\subsection{Conceptus Proteins (PSPB, PAG)}

Trophoblastic mono- and binucleate cells from the early bovine conceptus synthesize substantial amounts of proteins. Among these, one has been described as bPSPB (bovine pregnancy specific protein B) which enters into the maternal circulation [18]. In addition, a bPSPB related protein, designated bPAG (bovine pregnancy associated glycoprotein) [19] or bPAG1 [20] has been described. Bovine PSPB [21] and bPAG1 [20] are inactive aspartic acid proteinases, and are identical in genetic nucleotide sequence [22-24]. The isolated preparations of bPSPB and bPAG1 may differ in carbohydrate and sialic acid content, which may explain the minor differences in profile and disappearance from maternal circulation after calving or EM $[15,25,26]$. Because both bPSPB and bPAG1 are found in the maternal circulation during pregnancy, these proteins are good indicators of the presence of a live embryo. Both bPSPB and bPAG1 have been detected in the serum of some pregnant cows as early as days 15 to 22 [21, 27] or day 22 post-AI [28].

Due to delayed appearance of these proteins in the blood in some cows, the use of these proteins for PD provides more accurate results when used from Days 28 to 30 onwards [15, 16, 23, 29]. Both bPSPB and bPAG1 have been detected in peripheral circulation during the postpartum period 70 to 100 days after calving $[27,30]$. In a recent study, $56.7 \%$ and $44.9 \%$ of the false positive diagnoses based on bPSPB and bPAG1 tests, respectively, originated from cows that were inseminated within 70 days after calving [15]. These findings indicate that the presence of bPSPB and bPAG1 in the plasma of cows during early stages 
of the postpartum period may limit their use under field conditions. If only these cows are selected for the protein tests which are inseminated after day 50 [31] or day 70 [32-34], post calving interference with the residual bPSPB and bPAG1 in the peripheral circulation during the postpartum period can be minimal. A further limitation after LEM is that protein levels may remain above the threshold level, although the concentration of both proteins decreases steadily $[35,36]$. This is probably related to the relatively long half-life (7-8 days for bPSPB and 3-4 days for bPAG1) in the maternal circulation after EM [35, 37].

\subsection{Early Pregnancy Factor (EPF)}

The earliest specific indication for fertilization and the continuing presence of a viable conceptus is a serum constituent, which has been originally detected in mice [38]. This substance is known as EPF (early pregnancy factor) and has also been described in women [39], sheep [40], cattle [41] and pigs [42].

The reported and extraordinary properties of EPF include:

- Early appearance (within hours) after mating or insemination [39];

- Rapid disappearance following induced death or removal of the embryos [43, 44].

These factors suggest that EPF may be the most useful tool for investigating early embryonic survival or failure [44-46]. At present, the detection of EPF is entirely dependent on the use of the RIT (rosette inhibition test) which is a biological test therefore it is not practical. A new diagnostic test, the ECF (early conceptus factor) test, has been developed recently for the field $[47,48]$ however it cannot accurately identify conception within days or any time before Day 21 of gestation.

\section{Diagnosis of Pregnancy Losses}

One of the advantages of UEs is that PL can be recognised by the absence of a heartbeat, the detachment of the foetal membranes, the appearance of particles in the foetal fluids or the lack of the embryo proper [49, 50]. UEs have revealed that LEM may occur in up to $23 \%$ of pregnancies $[12,51]$. PL (8\%) diagnosed by ultrasonography in cows between days 26 and 58 post-AI occurred at approximately day $29(\mathrm{n}=1)$, day $33(\mathrm{n}=3)$, day $37(\mathrm{n}=3)$, day $40(\mathrm{n}=$ $2)$, day $44(\mathrm{n}=1)$ and day $56(\mathrm{n}=1)$ post-AI, respectively. The exact day of occurrence of LEM/EFM could not be determined because UE was performed at intervals of 3-4 days [36].

After diagnosing spontaneous cases of LEM by ultrasonography, both plasma bPSPB and bPAG1 levels began to decline in most cases, while the corpus luteum continued to produce progesterone [28, 36, 37]. This confirms the previous observations $[35,52]$ and demonstrates that lower progesterone concentrations are not the cause of conceptus death.

The potential clinical significance of diagnosing EM is that early ultrasonographic detection and prostaglandin treatment of cows with EM/FM may reduce the number of days before re-insemination [53].

\section{Prevention of Pregnancy Losses by Pharmacological Treatment}

Progesterone (P4) is unequivocally required for supporting gestation [54], pregnancy maintenance has been positively correlated to plasma concentrations of P4 on Week 5 of gestation [55], and P4 concentrations influence secretory functions of trophoblasts and pituitary during the first trimester of gestation [56]. However, one of the consequences of high milk production is an increased metabolic rate linked to a greater dry matter intake. This process reduces plasma concentrations of steroid hormones such as P4 and oestradiol (E2), with obvious impacts not only on fertility but also on gestation [57, 58]. Thus, milk production can affect negatively plasma steroid hormone concentrations during oestrus cycles after calving and/or at the onset of the foetal period $[59,60]$. Therefore, it seems reasonable to suppose that one of 
the causes of PL in high producing dairy cows could be the suboptimal concentrations of P4 and E2 [60, 61], either due to the increased steroid hormone catabolism, the sub-luteal function, or both. Thus, strategies that induce the formation of an additional corpus luteum by using human chorionic gonadotropin (hCG), gonadotropin realising hormone $(\mathrm{GnRH})$ or by enhancing the progesterone concentrations with gestagens [62, 63] may contribute to increase P4 concentrations in high producing dairy cows [6].

\subsection{Preventive Pharmaceutical Treatment at AI}

Pharmaceutical treatment at AI aims to improve PR by prevention of delayed ovulation and supporting the early luteal function as well as prevention of precocious luteolysis. Due to delayed ovulation precocious maturation changes take place on the oocyte which will reduce its fertilization and developmental capacity. Namely poor embryonic development is associated with low interferon- $\tau$ production, failed inhibition of luteolysis and EEM [64, 65]. A meta-analysis of the published results dealing with the treatment of dairy cows with GnRH at the time of insemination clearly demonstrates that $\mathrm{GnRH}$ analogue at the first post partum $\mathrm{AI}$, at the second service after calving and in repeat breeder cows may significantly increase PRs [66]. It is very important to remark that $\mathrm{GnRH}$ treatment at oestrus exposed to heat stress can also improve PRs [67, 68].

In contrast, treatments of dairy cows at AI with hCG failed to stimulate conception rates under field conditions $[69,70]$.

\subsection{Preventive Pharmaceutical Treatment in the Early Luteal Phase Post-AI}

Pharmaceutical treatment between days 4 and 7 post-AI aims to prevent EEM by inducing the formation of accessory corpora lutea, enhancing plasma progesterone concentrations and providing further LH support to the corpus luteum graviditatis [71]. Significant increase in PR was achieved when
hCG was given at Day $5[72,73]$ or at day $7[70,74$, 75], while hCG significantly increased PR only in some herds when it was given between days 4 and 9 post-AI [76]. In a recent study [77], hCG treatment on day 5 post-TAI could significantly increase PR only in heifers $(49.7 \%$ vs. $39.5 \%)$. In contrast, other studies reported a non-significant increase in PR when cows were treated with hCG between days 4 to 6 post-AI (14\%: [78]; 0.6\%: [79]; 3.9\%: [80]; 0.7\%: [81]; 2.3\% post-TAI: [82]; 0\%: [83]). At the same time a non-significant decrease in PR was reported when cows were treated with hCG on day 5 post-AI $(-2.7 \%$ : [84]; $-7.7 \%$ : [85]) or post-TAI $(-0.3 \%$ parity $>2$ : [77]).

Similarly GnRH may also induce formations of accessory corpora lutea however due to shorter duration of LH exposure they may produce less progesterone during the subsequent luteal phase [81]. GnRH treatment at Day 5 post-TAI could improve PR only in non-cycling cows [86] while GnRH treatment between days 4 and 9 post-AI was not able to improve PR [76]. PRID (progesterone realising intravaginal devices) or CIDR (controlled internal drug realising) inserts have also been used with inconsistent results between days 4 to 9 [76], or from day 5 [83, 86, 87] post-AI for 7 days. When, CIDR devices inserted into the vagina on day 4 and removed on day 18 post-AI had no positive effect on PR [88]. Similarly when PRID was used in repeat-breeder cows between days 5 to 19 post-AI, had no positive effect on PR, however when the animals were evaluated by parity and stage of lactation, PRID treatment significantly increased PR in the first and second parity late lactation cows [89]. At the same time PR at days 45 to 60 was also unaffected by the treatment of an injectable progesterone $(200 \mathrm{mg})$ on days $5,7,9$ and 11 post-AI [83].

\subsection{Preventive Pharmaceutical Treatment in Mid Luteal Phase Post-AI}

Several reports describe the use of a single GnRH injection between days 11 and 14 post-AI to increase 
PR $(0 \%$ to $23 \%)$ (meta-analysis: [90]). The scientific rationale for this treatment is to enhance embryo survival rates by delaying the luteolytic mechanism [91] which sometimes occurs by failure in maternal recognition of pregnancy. Some studies reported significant improvements of 10 to $12 \%$ in PRs [92-94] while others did not [95-97]. According to a recent study [98], treatment with GnRH at AI and 12 days later increased the PR in high yielding dairy cows during warm season.

The CIDR inserts increased embryo survival between days 29 and 57 post-TAI when treatment for 7 days starting on Day 13 post-TAI was performed [99]. Similarly, PRID also improved PR when used from Day 10 post-AI for 7 days [87].

\subsection{Preventive Pharmaceutical Treatment after Early Pregnancy Diagnosis around Day 30 post-AI}

Pregnant cows were supplemented with a PRID between days 36 and 42 post-AI for 28 days. Based on the odds ratio, the risk of PL was 2.4 times higher in non-treated cows than in treated ones: $12 \%(66 / 549)$ vs. $5.3 \%(29 / 549)$ of losses, respectively [100]. In a more recent study where treatment was started on day 28 of gestation, results were very similar: $16 \%(16 / 97)$ vs. $6 \%(6 / 102)$ losses for non-treated and treated cows, respectively [101]. These results support the hypothesis that sub-optimal progesterone concentrations in high producing dairy cows may compromise conceptus development. Under these conditions, intra-vaginal progesterone supplementation has the potential to reduce the incidence of PL during LE/EF period.

According to a recent study in herds with a high incidence of EFM of a non-infectious nature at PD (days 28-34), treatment at the time of PD with progesterone in cows with one corpus luteum and with GnRH in cows with two or more corpora lutea should offer considerable benefits [102].

\section{References}

[1] Roche, J. F., Boland, M. P., and McGeady, T. A. 1981.
"Reproductive Wastage Following Artificial Insemination in Cattle." Veterinary Record 109: 95-7.

[2] López-Gatius, F. 2003. "Is Fertility Declining in Dairy Cattle? A Retrospective Study in Northeastern Spain." Theriogenology 60: 89-99.

[3] Galon, N. 2008. "Factors Affecting Reproductive Performance in Israeli Dairy Herds." In Factors Affecting Reproductive Performance in the Cow, edited by Szenci, O., and Bajcsy, Á. Cs. Budapest: Hungarian Association for Buiatrics.

[4] Bouchard, E., and Tremblay, D. Du. 2008. "Dairy Herd Production and Reproduction in Quebec and Canada." In Factors Affecting Reproductive Performance in the Cow, edited by Szenci, O., Bajcsy, Á. Cs. Budapest: Hungarian Association for Buiatrics.

[5] Nakao, T. 2008. "Declining Fertility in Dairy Cows in Japan and Efforts to Improve the Fertility." In Factors Affecting Reproductive Performance in the Cow, edited by Szenci, O., and Bajcsy, Á. Cs. Budapest: Hungarian Association for Buiatrics.

[6] López-Gatius, F., Szenci, O., Bech-Sàbat, G., García-Ispierto, I., Serrano, B., and Santolaria, P. 2009. "Factors of Non-infectious Nature Affecting Late Embryonic and Early Foetal Loss in High Producing Dairy Herds in North-Eastern Spain.” Magyar Állatorvosok Lapja 131: 515-31.

[7] Taverne, M. A. M., Szenci, O., Szétag, J., and Piros, A. 1985. "Pregnancy Diagnosis in Cows with Linear-array Real-time Ultrasound Technique: a Preliminary Note." Veterinary Quarterly 7: 264-70.

[8] Curran, S., Pierson, R. A., and Ginther, O. J. 1986. "Ultrasonographic Appearance of the Bovine Conceptus from Days 10 through 20." Journal of American Veterinary Medicine Association 189: 1289-94.

[9] Curran, S., Pierson, R. A., and Ginther, O. J. 1986. "Ultrasonographic Appearance of the Bovine Conceptus from Days 20 through 60." Journal of American Veterinary Medicine Association 189: 1295-302.

[10] Pieterse, M. C., Szenci, O., Willemse, A. H., Bajcsy, A. C., Dieleman, S. J., and Taverne, M. A. M. 1990. "Early Pregnancy Diagnosis in Cattle by Means of Linear-Array Real-Time Ultrasound Scanning of the Uterus and a Quantitative and Qualitative Milk Progesterone Test.” Theriogenology 33: 697-707.

[11] Szenci, O., Piros, A., and Kovács, L. 1990. "Early Bovine Pregnancy Diagnosis by a Battery Operated Portable Ultrasonic Scanner the Ultra-Scan." In Proceedings of the 16th World Buiatrics Congress, 219-23.

[12] Hanzen, C., and Laurent, Y. 1991. "Application de L'echographie Bidimensionnelle au Diagnostic de Gestation et L'evaluation de L'incidence de la Mortalit, Embryonnaire dans L'espece Bovine.” Annales Medicine 
Veterinaries 134: 481-7.

[13] Badtram, G. A., Gaines, J. D., Thomas, C. B., and Bosu, W. T. K. 1991. "Factors Influencing the Accuracy of Early Pregnancy Detection in Cattle by Real-time Ultrasound Scanning of the Uterus." Theriogenology 35: 1153-67.

[14] Romano, J. E., Thompson, J. A., Forrest, D. W., and Westhusin, M. E., Tomaszweski, M. A., Kraemer, D. C. 2006. "Early Pregnancy Diagnosis by Transrectal Ultrasonography in Dairy Cattle." Theriogenology 66: 1034-41.

[15] Szenci, O., Beckers, J. F., Humblot, P., Sulon, J., Sasser, G., and Taverne, M. A. M. 1998. "Comparison of Ultrasonography Bovine Pregnancy-Specific Protein B, and Bovine Pregnancy-Associated Glycoprotein 1 Tests for Pregnancy Detection in Dairy Cows." Theriogenology 50: 77-88.

[16] Szenci, O., Taverne, M. A. M., Beckers, J. F., Sulon, J., Varga, J., and Börzsönyi, L. 1998. "Evaluation of False Ultrasonographic Diagnoses in Cows Measuring Plasma Levels of Bovine Pregnancy Associated (bPAG)." Veterinary Record 142: 304-6.

[17] Szenci, O., Gyulai, G., Nagy, P., Kovács, L., Varga, J., and Taverne, M. A. M. 1995. "Effect of Uterus Position Relative to the Pelvic Inlet on the Accuracy of Early Bovine Pregnancy Diagnosis by Means of Ultrasonography." The Veterinary Quarterly 17: 37-9.

[18] Butler, J. E., Hamilton, W. C., Sasser, R. G., Ruder, C. A., Hass, G. M., and Williams, R. J. 1982. "Detection and Partial Characterization of Two Bovine Pregnancy-Specific Proteins." Biology of Reproduction 26: 925-33

[19] Zoli, A. P., Beckers, J. F., Wouters-Ballman, P., Closset, J., Falmagne, P., and Ectors, F. 1991. "Purification and Characterization of a Bovine Pregnancy Associated Glycoprotein." Biology of Reproduction 45: 1-10.

[20] Xie, S., Low, B. G., Nagel, R. J., Kramer, K. K., Anthony, R. V., and Zoli, A. P. 1991. "Identification of the Major Pregnancy-Specific Antigens of Cattle and Sheep as Inactive Members of the Aspartic Proteinase Family." Proceedings of the National Academy of Sciences of the United States of America 88: 10247-51.

[21] Sasser, R. G., Ruder, C. A., Ivani, K. A., Butler, J. E., and Hamilton, W. C. 1986. "Detection of Pregnancy by Radioimmunoassay of a Novel Pregnancy-Specific Protein in Serum of Cows and a Profile of Serum Concentrations during Gestation." Biology of Reproduction 35: 936-42.

[22] Lynch, R. A., Alexander, B. M., and Sasser, R. G. 1992. "The Cloning and Expression of the Pregnancy-Specific Protein B (bPSPB) Gene.” Biology of Reproduction 46 (Suppl. 1): 72.
[23] Vasquez, M. I., Horta, A. E. M., Marques, C. C., Sasser, R. G., and Humblot, P. 1995. "Levels of bPSPB Throughout Single and Twin Pregnancies after AI or Transfer of IVM/IVF Cattle Embryos.” Animal Reproduction Science 38: 279-89.

[24] Xie, S., Green, J., Beckers, J. F., and Roberts, R. M. 1995. "The Gene Encoding Bovine Pregnancy-Associated Glycoprotein-1, an Inactive Member of the Aspartic Proteinase Family." Gene 159: 193-7.

[25] Beckers, J. F., Zarrouk, A., Batalha, E. S., Garbayo, J. M., Mester, L., and Szenci, O. 1998. "Endocrinology of Pregnancy: Chorionic Somatomammotropins and Pregnancy-Associated Glycoproteins: Review." Acta Veterinaria Hungarica 46: 175-89.

[26] Beckers, J. F., Drion, P. V., Garbayo, J. M., Perényi, Z., Zarrouk, A., and Sulon, J. 1999. "Pregnancy Associated Glycoproteins in Ruminants: Inactive Members of the Aspartic Proteinase Family." Acta Veterinaria Hungarica 47: 461-9.

[27] Zoli, A. P., Guilbault, L. A., Delahaut, P., Ortiz, W. B., and Beckers, J. F. 1992. "Radioimmunoassay of a Bovine Pregnancy-Associated Glycoprotein in Serum: Its Application for Pregnancy Diagnosis." Biology Reproduction 46: 83-92.

[28] Giordano, J. O., Guenther, J. N., Lopes, G., and Fricke, P. M. 2012. "Changes in Serum Pregnancy-Associated Glycoprotein, Pregnancy-Specific Protein B, and Progesterone Concentrations before and after Induction of Pregnancy Loss in Lactating Dairy Cows." Journal of Dairy Science 95: 683-97.

[29] Humblot, P., Jeanguyot, N., Ruder, C. A., Leriche, I., Thibier, M., and Sasser, R. G. 1988. "Accuracy of Pregnancy Diagnosis by PSPB RIA in the Plasma of Dairy Cows 28 Days after AI." In Proceedings of the 11th International Congress on Animal Reproduction and Artificial Insemination, 3.

[30] Kirakofe, G. H., Wright, J. M., Schalles, R. R., Ruder, C. A., Paris, S., and Sasser, R. G. 1993. "Pregnancy-Specific Protein B in Serum of Postpartum Beef Cows." Journal of Animal Science 71: 2199-205.

[31] Sasser, R. G., Alexander, B. M., and Ruder, C. A. 1991. "Pregnancy Detection in Postpartum Cows by Measurement of Pregnancy Specific Protein B (PSPB)." Journal of Animal Science 69: 660.

[32] Ruder, C. A., and Sasser, R. G. 1986. "Source of Bovine Pregnancy-Specific Protein B (bPSPB) during the Postpartum Period and Estimation of Half-Life of bPSPB." Journal of Animal Science 63: 335.

[33] Humblot, P., Camous, S., Martal, J., Charlery, J., Jeanguyot, N., and Thibier, M. 1988. "Pregnancy Specific Protein B, Progesterone Concentrations and Embryonic Mortality during Early Pregnancy in Dairy Cows." 
Journal of Reproduction and Fertility 83: 215-23.

[34] Humblot, P., Camous, S., Martal, J., Charlery, J., Jeanguyot, N., and Thibier, M. 1988. "Diagnosis of Pregnancy by Radioimmunoassay of a Pregnancy-Specific Protein in the Plasma of Dairy Cows." Theriogenology 30: 257-67.

[35] Semambo, D. K. N., Eckersall, P. D., Sasser, R. G., and Ayliffe, T. R. 1992. "Pregnancy-Specific Protein B and Progesterone in Monitoring Viability of the Embryo in Early Pregnancy in the Cow after Experimental Infection with Actinomyces Pyogenes." Theriogenology 37: 741-8.

[36] Szenci, O., Humblot, P., Beckers, J. F., Sasser, G., Sulon, J., and Baltusen, R. 2000. "Plasma Profiles of Progesterone and Conceptus Proteins in Cows with Spontaneous Embryonic/Foetal Mortality as Diagnosed by Ultrasonography." Veterinary Journal 159: 287-90.

[37] Szenci, O., Beckers, J. F., Sulon, J., Bevers, M. M., Börzsönyi, L., and Fodor, L. 2003. "Effect of Induction of Late Embryonic Mortality on Plasma Profiles of Pregnancy Associated Glycoproteins in Heifers." Veterinary Journal 165: 307-13.

[38] Morton, H., Hegh, V., and Clunie, G. J. A. 1974. "Immunosuppression Detected in Pregnant Mice by Rosette Inhibition." Nature 249: 459-60.

[39] Morton, H., Rolfe, B. E., Anderson, M., and Morrison, J. 1977. "An Early Pregnancy Factor Detected in Human Serum by Rosette Inhibition Test." Lancet 1: 394-7.

[40] Morton, H., Clunie, G. J. A., and Shaw, F. D. 1979. "A Test for Early Pregnancy in Sheep." Research in Veterinary Science 26: 261-2.

[41] Nancarrow, C. D., Wallace, A. L. L., and Grewal, A. S. 1971. "The Early Pregnancy Factor of Sheep and Cattle." Journal of Reproduction and Fertility 30: 191-7.

[42] Paisley, L. G., Davis, W. C., Anderson, P. B., and Mickelsen, W. D. 1982. "Detection of Early Pregnancy Factor in Swine: A Need for Dialogue.” Theriogenology 18: 393-401.

[43] Rolfe, B., Cavanagh, A., Forde, C., Bastin, F., Chen, C., and Morton, H. 1984. "Modified Rosette Inhibition Test with Mouse Lymphocytes for Detection of Early Pregnancy Factor in Human Pregnancy Serum.” Journal of Immunological Methods 70: 1-11.

[44] Yamazaki, S., Kawahata, K., Goto, T., Takahashi, J., Yasuda, Y. 1995. "EPF as a Marker for Early Embryonic Losses in Repeat Breeders." Journal of Reproduction and Development 41: 129-32.

[45] Rolfe, B. 1982. "Detection of Foetal Wastage." Fertility and Sterility 37: 655-60.

[46] Koch, E. 1986. "Early Pregnancy Factor: Its Significance as an Indicator of Fertilization and Embryonic Mortality." In Embryonic Mortality in Farm Animals, edited by
Screenan, J. M., and Dordrecht, M. G. Diskin: Martinus Nijhoff Publishers.

[47] Cordoba, M. C., Sartori, R., and Fricke, P. M. 2001. "Assessment of a Commercially Available Early Conception Factor (ECF) Test for Determining Pregnancy Status of Dairy Cattle." Journal of Dairy Science 84: 1884-9.

[48] Gandy, B., Tucker, W., Ryan, P., Williams, A., Tucker, A., and Moore, A. 2001. "Evaluation of the Early Conception Factor (ECFTM) Test for the Detection of Nonpregnancy in Dairy Cattle." Theriogenology 56: 637-47.

[49] Kastelic, J. P., Bergfelt, D. R., and Ginther, O. J. 1991. "Ultrasonic Detection of the Conceptus and Characterisation of Intrauterine Fluid on Days 10 to 22 in Heifers." Theriogenology 35: 569-81.

[50] Semambo, D. K. N., Boyd, J. S., Taylor, D. J., Ayliffe, T. R., and Omran, S. N. 1992. "Ultrasonographic Study of Early Embryonic Loss Induced by Actinomyces Pyogenes in Cattle." Veterinary Record 131: 7-12.

[51] Chaffaux, S., Reddy, G. N. S., Valon, F., and Thibier, M. 1986. "Transrectal Real-Time Ultrasound Scanning for Diagnosing Pregnancy and for Monitoring Embryonic Mortality in Dairy Cattle." Animal Reproduction Science 10: 193-200.

[52] Kastelic, J. P., Northey, D. L., and Ginther, O. J. 1991. "Spontaneous Embryonic Death on Days 20 to 40 in Heifers." Theriogenology 35: 361-3.

[53] Baxter, S. J., and Ward, W. R. 1997. "Incidence of Fetal Loss in Dairy Cattle after Pregnancy Diagnosis Using an Ultrasound Scanner." Veterinary Record 140: 287-8.

[54] Spencer, T. E., Johnson, G. A., Burghart, R. C., and Bazer, F. W. 2004. "Progesterone and Placental Hormone Actions on the Uterus: Insights from Domestic Animals." Biology of Reproduction 71: 2-10.

[55] Starbuck, M. J., Dailey, R. A., and Inskeep, E. K. 2004. "Factors Affecting Retention of Early Pregnancy in Dairy Cattle." Animal Reproduction Science 84: 27-39.

[56] Ayad, A., Sousa, N. M., Sulon, J., Hornick, J. L., Watts, J., and López-Gatius, F. 2007. "Influence of Progesterone Concentrations on Secretory Functions of Trophoblast and Pituitary During the First Trimester of Pregnancy in Dairy Cattle." Theriogenology 67: 1503-11.

[57] Sangsritavong, S., Combs, D. K., Sartori, R., Armentano, L. E., and Wiltbank, M. C. 2002. "High Feed Intake Increases Liver Blood Flow and Metabolism of Progesterone and Estradiol-17 $\beta$ in Dairy Cattle.” Journal of Dairy Science 85: 2831-42.

[58] Wiltbank, M. C., Lopez, H., Sartori, R., Sangsritavong, S., and Gümen, A. 2006. "Changes in Reproductive Physiology of Lactating Dairy Cows Due to Elevated Steroid Metabolism.” Theriogenology 65: 17-29. 
[59] Bech-Sàbat, G., López-Gatius, F., Yániz, J. L., García-Ispierto, I., Santolaria, P., and Serrano, B. 2008. "Factors Affecting Plasma Progesterone in the Early Fetal Period in High Producing Dairy Cows." Theriogenology 69: 426-32.

[60] Pursley, J. R., and Martins, P. N. 2012. "Impact of Circulating Concentrations of Progesterone and Antral Age of the Ovulatory Follicle on Fertility of High-Producing Lactating Dairy Cows." Reproduction Fertility and Development 24: 267-71.

[61] Sartori, R., Haughian, J. M., Shaver, R. D., Rosa, G. J., and Wiltbank, M. C. 2004. "Comparison of Ovarian Function and Circulating Steroids in Estrous Cycles of Holstein Heifers and Lactating Cows." Journal of Dairy Science 87: 905-20.

[62] De Rensis, F., Lopez-Gatius, F., Garcia-Ispierto, I., Techakumpu, M. 2010. "Clinical Use of Human Chorionic Gonadotropin in Dairy Cows: An Update." Theriogenology 73: 1001-8.

[63] Thatcher, W. W., Bilby, T. R., Bartolome, J. A., Silvestre, F., Staples, C. R., and Santos, J. E. 2006. "Strategies for Improving Fertility in the Modern Dairy Cow." Theriogenology 65: 30-44.

[64] Mann, G. E., Mann, S. J., and Lamming, G. E. 1996. "The Interrelationship Between the Maternal Hormone Environment and the Embryo During the Early Stage of Pregnancy." Journal of Reproduction and Fertility 17: 55 (Abstract Series).

[65] Mann, G. E., Lamming, G. E., and Fisher, P. A. 1998. "Progesterone Control of Embryonic Interferon- $\tau$ Production During Early Pregnancy in the Cow." Journal of Reproduction and Fertility 21: 37 (Abstract Series).

[66] Morgan, W. F., and Lean, I. J. 1993. "Gonadotrophin-Releasing Hormone Treatment in Cattle: A Meta-Analysis of the Effects on Conception at the Time of Insemination." Australian Veterinary Journal 70: 205-9.

[67] Ullah, G., Fuquay, J. W., Keawhoong, T., Clark, B. L., Pogue, D. E., and Murphy, E. J. 1996. "Effect of Gonadotrophin-Releasing Hormone at Estrus on Subsequent Luteal Function and Fertility in Lactating Holstein During Heat Stress." Journal of Dairy Science 79: 1950-3.

[68] Kaim, M., Bloch, A., Wolfenson, D., Braw-Tal, R., Rosenberg, M., and Voet, H. 2003. "Effects of GnRH Administered to Cows at the Onset of Estrus on Timing of Ovulation, Endocrine Responses, and Conception." Journal of Dairy Science 86: 2012-21.

[69] Hansel, W., Spalding, R. W., Larson, L. L., Laster, D. B., Wagner, J. F., and Braun, R. K. 1979. "Influences of Human Chorionic Gonadotropin on Pregnancy Rates in Lactating Dairy and Beef Cows." Journal of Dairy
Science 59: 751-4.

[70] Rajamahendran, R., and Sianangama, P. C. 1992. "Effect of Human Chorionic Gonadotrophin on Dominant Follicles in Cows: Formation of Accessory Corpora Lutea, Progesterone Production and Pregnancy Rates." Journal of Reproduction and Fertility 95: 577-84.

[71] Binelli, M., Machado, R., Bergamaschi, M. A. C. M., and Bertan, C. M. 2009. "Manipulation of Ovarian and Uterine Function to Increase Conception Rates in Cattle." Animal Reproduction 6: 125-34.

[72] Kerbler, T. L., Buhr, M. M., Jordan, L. T., Leslie, K. E., and Walton, J. S. 1997. "Relationship Between Maternal Plasma Progesterone Concentration and Interferon-Tau Synthesis by the Conceptus in Cattle." Theriogenology 47: 703-14.

[73] Santos, J. E., Thatcher, W. W., Pool, L., and Overton, M. W. 2001. "Effect of Human Chorionic Gonadotropin on Luteal Function and Reproductive Performance of High-Producing Lactating Holstein Dairy Cows.” Journal of Animal Science 79: 2881-94.

[74] Breuel, K. F., Spitzer, J. C., and Henricks, D. M. 1989. "Systemic Progesterone Concentration Following Human Chorionic Gonadotropin Administration at Various Times during the Estrous Cycle in Beef Heifers." Journal of Animal Science 67: 1564-72.

[75] Sianangama, P. C., and Rajamahendran, R. 1992. "Effect of Human Chorionic Gonadotropin Administered at Specific Times Following Breeding on Milk Progesterone and Pregnancy in Cows." Theriogenology 38: 85-96.

[76] Stevenson, J. S., Portaluppi, M. A., Tenhouse, D. E., Lloyd, A., Eborn, D. R., Kacuba, S., 2007. "Interventions after Artificial Insemination: Conception Rates, Pregnancy Survival, and Ovarian Responses to Gonadotropin-Releasing Hormone, Human Chorionic Gonadotropin, and Progesterone." Journal of Dairy Science 90: 331-40.

[77] Nascimento, A. B., Bender, R. W., Souza, A. H., Ayres, H., Araujo, R. R., and Guenther, J. N. 2013. "Effect of Treatment with Human Chorionic Gonadotropin on Day 5 after Timed Artificial Insemination on Fertility of Lactating Dairy Cows." Journal of Dairy Science 96: 2873-82.

[78] Beltran, M. P., and Vasconcelos, J. L. M. 2008. "Conception Rate in Holstein Cows Treated with GnRH or hCG on the Fifth Day Post Artificial Insemination During Summer." Arquivo Brasileiro de Medicina Veterinária e Zootecnia 60: 580-6.

[79] Fischer-Tenhagen, C., Thiele, G., Heuwieser, W., Tenhagen, B. A. 2010. "Efficacy of a Treatment with hCG 4 Days After AI to Reduce Pregnancy Losses in Lactating Dairy Cows after Synchronized Ovulation." Reproduction in Domestic Animal 45: 468-72. 
[80] Kendall, N. R., Flint, A. P., and Mann, G. E. 2009. "Incidence and Treatment of Inadequate Postovulatory Progesterone Concentrations in Repeat Breeder Cows." Veterinary Journal 181: 158-62.

[81] Schmitt, E. J., Barros, C. M., Fields, P. A., Fields, M. J., Diaz, T., and Kluge, J. M. 1996. "A Cellular and Endocrine Characterization of the Original and Induced Corpus Luteum after Administration of a Gonadotropin-Releasing Hormone Agonist or Human Chorionic Gonadotropin on Day Five of the Estrous Cycle." Journal of Animal Science 74: 1915-29.

[82] Vasconcelos, J. L., Filho, S. O. G., Justolin, P. L., Morelli, P., Aragon, F. L., and Veras, M. B. 2011. "Effects of Postbreeding Gonadotropin Treatments on Conception Rates of Lactating Dairy Cows Subjected to Timed Artificial Insemination or Embryo Transfer in a Tropical Environment." Journal of Dairy Science 94: 223-34.

[83] Walton, J. S., Halbert, G. W., Robinson, N. A., and Leslie, K. E. 1990. "Effects of Progesterone and Human Chorionic Gonadotrophin Administration Five Days Post Insemination on Plasma and Milk Concentrations of Progesterone and Pregnancy Rates of Normal and Repeat Breeder Dairy Cows." Canadian Journal of Veterinary Research 54: 305-8.

[84] Hanlon, D. W., Jarratt, G. M., Davidson, P. J., Millar, A. J., and Douglas, V. L. 2005. "The Effect of hCG Administration Five Days After Insemination on the First Service Conception Rate of Anestrous Dairy Cows." Theriogenology 63: 1938-45.

[85] Shams-Esfandabadi, N., Shirazi, A., Mirshokrai, P., and Bonyadian, M. 2007. "Influence of hCG Administration After AI on Conception Rates and Serum Progesterone Concentration in Cattle." Pakistan Journal of Biological Sciences 10: 2709-13.

[86] Sterry, R. A., Welle, M. L., and Fricke, P. M. 2006. "Treatment with Gonadotropin-Releasing Hormone after First Timed Artificial Insemination Improves Fertility in Noncycling Lactating Dairy Cows." Journal of Dairy Science 89: 4237-45.

[87] Robinson, N. A., Leslie, K. E., and Walton, J. S. 1989. "Effect of Treatment with Progesterone on Pregnancy Rate and Plasma Concentrations of Progesterone in Holstein Cows." Journal of Dairy Science 72: 202-7.

[88] Arndt, W. J., Holle, A. J., Bauer, M. L., Kirsch, J. D., Schimek, D. E., and Odde, K. G. 2009. "Effect of Post-insemination Progesterone Supplementation on Pregnancy Rate in Dairy Cows." Canadian Journal of Veterinary Research 73: 271-4.

[89] Villarroel, A., Martino, A., BonDurant, R. H., Dèletang, F., and Sischo, W. M. 2004. "Effect of Post-insemination Supplementation with PRID on Pregnancy in
Repeat-Breeder Holstein Cows." Theriogenology 61: 1513-20.

[90] Peters, A. R., Martinez, T. A., and Cook, A. J. C. 2000. "A Meta-Analysis of Studies of the Effect of GnRH 11-14 Days after Insemination on Pregnancy Rates in Cattle." Theriogenology 54: 1317-26.

[91] Mann, G. E., Lamming, G. E., and Fray, M. D. 1995. "Plasma Oestradiol and Progesterone during Early Pregnancy in the Cow and the Effects of Treatment with Buserelin." Animal Reproduction Science 37: 121-31.

[92] Macmillan, K. L., Taufa, V. K., and Day, A. M. 1986. "Effects on an Agonist of Gonadotrophin Realizing Hormone (Buserelin) in Cattle. III: Pregnancy Rates after a Post-Insemination injection during Metoestrus or Dioestrus." Animal Reproduction Science 11: 1-10.

[93] Sheldon, I. M., and Dobson, H. 1993. "Effects of Gonadotrophin Releasing Hormone Administered 11 Days after Insemination on the Pregnancy Rates of Cattle to the First and Later Services." Veterinary Record 133: 160-3.

[94] Drew, S. B., and Peters, A. R. 1994. "Effect of Buserelin on Pregnancy Rates in Dairy Cows." Veterinary Record 134: 267-9.

[95] Jubb, T. F., Abhayaratne, D., Malmo, J., and Anderson, G. A. 1990. "Failure of an Intramuscular Injection of an Analogue of Gonadotrophin-Releasing Hormone 11 to 13 Days after Insemination to Increase Pregnancy Rates in Dairy Cattle." Australian Veterinary Journal 67: 359-61.

[96] Ryan, D. P., Snijders, S., Condon, T., Grealy, M., Sreenan, J., and O'Farrell, K. J. 1994. "Endocrine and Ovarian Responses and Pregnancy Rates in Dairy Cows Following the Administration of a Gonadotrophin Releasing Hormone Analog at the Time of Artificial Insemination or at Mid-cycle Post Insemination.” Animal Reproduction Science 34: 179-91.

[97] Szenci, O., Takács, E., Sulon, J., Sousa, N. M., Beckers, J. F. 2006. "Evaluation of the Use of GnRH 12 Days after AI on Reproductive Performance in Dairy Cows." Theriogenology 66: 1811-5.

[98] López-Gatius, F., Santolaria, P., Martino, A., Delétang, F., and Rensis, F. D., 2006. "The Effects of GnRH Treatment at the Time of AI and 12 Days Later on Reproductive Performance of High Producing Dairy Cows During the Warm Season in Northeastern Spain." Theriogenology 65: 820-30.

[99] El-Zarkouny, S. Z., and Stevenson, J. S. 2004. "Resynchronizing Estrus With Progesterone or Progesterone Plus Estrogen In Cows Of Unknown Pregnancy Status." Journal of Dairy Science 87: 3306-21.

[100] López-Gatius, F., Santolaria, P., Yániz, J. L., and Hunter, R. H. F. 2004. "Progesterone Supplementation during the 
180 Recent Possibilities for the Diagnosis and Pharmacological Control of Pregnancy Loss in Dairy Cow

Early Fetal Period Reduces Pregnancy Loss in High-Yielding Dairy cattle." Theriogenology 62: 1529-35.

[101] Bech-Sàbat, G., García-Ispierto, I., Yániz, J. L., and López-Gatius, F. 2007. "High Milk Production Increases the Risk of Early Fetal Loss in Dairy Cows."
Reproduction in Domestic Animal 42 (S2): 122(Abstract). [102] Bech-Sàbat, G., López-Gatius, F., García-Ispierto, I., Santolaria, J. P., and Serrano, B. 2009. "Pregnancy Patterns during the Early Fetal Period in High Producing Dairy Cows Treated with GnRH or Progesterone." Theriogenology 71: 920-9. 